\title{
Geographical and experimental assessment of the distribution of Gracilaria species (Rhodophyta: Gigartinales) in relation to temperature ${ }^{*, * *}$
}

\author{
J. McLachlan \& C. J. Bird
}

National Research Council of Canada; 1411 Oxford Street, Halifax, NS, Canada B3H $3 Z 1$

\begin{abstract}
Tolerance and growth at temperatures from $0^{\circ}$ to $36^{\circ} \mathrm{C}$ were investigated using 15 species and strains of Gracilaria Grev. isolated from tropical and temperate coasts of the Atlantic and eastern Pacific Oceans. All survived a minimum of $15^{\circ} \mathrm{C}$ and, with two exceptions, a maximum of $28^{\circ} \mathrm{C}$. Only two species tolerated $34^{\circ} \mathrm{C}$ and none $36^{\circ} \mathrm{C}$ which was rapidly lethal. Isolates intolerant of temperatures less than $15^{\circ} \mathrm{C}$ were generally species known only from tropical waters, whereas species isolated from temperate waters tended to be eurythermal, and most seemed not to be restricted to cooler waters. Maximum growth of warm-water isolates tended to occur over a broad range of warmer temperatures, $20^{\circ} \mathrm{C}$ and higher, and usually extended to the upper limits of thermal tolerance. Isolates from temperate waters showed maximum growth at $20^{\circ}$ or $15^{\circ} \mathrm{C}$, and there was no appreciable growth of any of the isolates below $10^{\circ} \mathrm{C}$. These experimental results are in accord with known distributional patterns of Gracilaria. There is a correlation between temperature and number of species, with most species reported from warm-water areas where the mean water temperature is $25^{\circ} \mathrm{C}$ or more. Where the 3 -month mean minimum temperature is less than $20^{\circ} \mathrm{C}$, there is a rapid decline in number of species. In the eastern Atlantic, the relationship is less obvious as few species have been reported from the warm-water region. This is quite likely the result of other environmental factors.
\end{abstract}

\section{INTRODUCTION}

The genus Gracilaria Greville is one of the largest genera of red algae in terms of number of species. It is, moreover, a very widely distributed genus, occurring in all oceans except the Arctic. This size and wide distribution make it ideally suited for biogeographic analysis.

The infrageneric taxonomy of Gracilaria is, however, chaotic. Many of the species are poorly known, often leading to incorrect identification and thus to misrepresentation of geographic distribution. For example, G. verrucosa (Huds.) Papenf. has been reported the world over, in cold, temperate, and warm waters, which biogeographically is an unusual situation. We have questioned some of these reports, and further, have suggested that $G$. verrucosa may be confined to the northeastern Atlantic (Bird et al., 1982).

- NRCC No. 23817

- Paper presented at the Seaweed Biogeography Workshop of the International Working Group on Seaweed Biogeography, held from 3-7 April 1984 at the Department of Marine Biology, Rijksuniversiteit Groningen (The Netherlands), Convenor: C. van den Hoek. 
Whether or not this is correct, the point is made that we cannot define the geographic range of $G$. verrucosa, or indeed of many other species of Gracilaria, with any degree of certainty because our concepts of these species are faulty or incomplete. Nevertheless, biogeographic studies should complement taxonomic concepts and can lead to a more accurate interpretation of the species. We are restricting our present considerations to the continents of North and South America, and the Atlantic coasts of Europe and Africa, where the Gracilaria floras are reasonably well known; better, at least to us, than in other parts of the world. Even within this geographic scope, there are areas for which floristic data on algae are relatively meagre or even lacking. These are, mainly, the southern Caribbean Sea, northern Brasil, southern South America, much of the tropical Pacific, and southwestern Africa. Such gaps in our knowledge pose a serious problem should these areas lie in zones of floristic transition.

It is generally accepted that temperature is a major, if not the foremost environmental factor determining the distribution of marine algae (e.g. Druehl, 1981; van den Hoek, 1982). Our basic premise in this instance is that Gracilaria is primarily a warm-water genus. This is supported by the greater number of species reported from the tropics (e.g. Taylor, 1960; Dawson, 1961a, b; Lawson \& John, 1982) and by a rapid reduction in species numbers with increasing latitude (Bird et al., 1982; Oliveira, 1984). This trend seems well established notwithstanding the uncertain taxonomiy; i.e. the many tropical entities appear, on the whole, to be distinct, reproductively isolated species (cf. Hay \& Norris, 19847 and not merely extreme morphological variants of one or a few taxa.

The extensive north-south coastlines of the Americas and, to a lesser extent, of Europe and west Africa, provide an opportunity for observing the distribution of Gracilaria along continuous thermal gradients. These gradients are, however, complicated by major ecological barriers that truncate potential distributional ranges or create discontinuities. These barriers may be unfavourable conditions such as fresh water, turbidity and unstable substrate, or headlands and upwelling that abruptly alter temperature by deflecting currents. The Carolina Barrens, the turbid coastal waters of tropical Africa, and the outflows of the Amazon, Orinoco and Plata rivers are only a few examples of significant biogeographical barriers. Additionally, local habitats may differ substantially from the general hydrographic features of the area, and yet their particular properties may account for the presence or absence of certain species.

It has been emphasized that, with respect to marine algal biogeography (e.g., Druehl, 1981; Round, 1981), established relationships between distribution and environmental parameters have nearly always been based on correlation rather than experimental evidence. In the following text, we present data on thermal tolerance of various species of Gracilaria from widely different sources. These experimental data are collated with previous reports on distribution and thermal regimes in the areas under consideration, to examine the assumption that temperature is the main abiotic factor controlling the distribution of this genus.

\section{MATERIALS AND METHODS}

The species and strains used for experimental purposes were from uni-algal cultures available in our laboratory (Table 1). Several strains obtained from Hawail are included as representatives from warm-water environments although Hawaii is, strictly speaking, outside our geographic scope. Apical segments of female gametophytes were used 
Table 1. Species of Gracilaria used in the temperature experiments, and the temperature range of the habitats from which the plants were collected

\begin{tabular}{|c|c|c|c|c|c|}
\hline Strain and origin & Code & $\begin{array}{l}\text { Tempera- } \\
\text { ture } \\
\left({ }^{\circ} \mathrm{C}\right) \\
\text { range }\end{array}$ & Strain and origin & Code & $\begin{array}{l}\text { Tempera- } \\
\text { ture } \\
\left({ }^{\circ} \mathrm{C}\right) \\
\text { range }\end{array}$ \\
\hline \multirow{2}{*}{$\begin{array}{l}\text { G. tikvahiae } \\
\text { McLachlan } \\
\text { (Nova Scotia) }\end{array}$} & BAR & $<0-=25$ & $\begin{array}{l}\text { G. debilis (Forsk.) } \\
\text { Børg. (St. Lucia) }\end{array}$ & DEB & $27-29$ \\
\hline & GTF & $16-30$ & $\begin{array}{l}\text { Gracilaria sp. } \\
\text { (St. Lucia) }\end{array}$ & GT & $27-29$ \\
\hline $\begin{array}{l}\text { G. foliifera } \\
\text { (Forsk.) Børg. } \\
\text { (So. Devon, UK) }\end{array}$ & FOL & $5-20$ & $\begin{array}{l}\text { G. mammillaris } \\
\text { (Mont.) Howe } \\
\text { (Tampa Bay, FL) }\end{array}$ & MAM & $16-30$ \\
\hline \multirow{2}{*}{$\begin{array}{l}\text { G. bursa-pastoris } \\
\text { (Gmel.) Silva } \\
\text { (Isle of Wight, UK) }\end{array}$} & BPUK & $5-20$ & $\begin{array}{l}\text { Gracilaria sp. } \\
\text { (Vancouver I.) }\end{array}$ & VI & $8-12$ \\
\hline & & & $\begin{array}{l}\text { G. lemaneiformis } \\
\text { (Bory) }\end{array}$ & MJ & \\
\hline $\begin{array}{l}\text { Gracilaria sp. } \\
\text { (Adriatic Sea) }\end{array}$ & ITA & $7-24$ & $\begin{array}{l}\text { Weber-v.-Bosse } \\
\text { (Mejillones, Chile) }\end{array}$ & & \\
\hline $\begin{array}{l}\text { Gracilaria sp. } \\
\text { (San Diego, CA) }\end{array}$ & $\mathrm{CA}$ & $12-23$ & $\begin{array}{l}\text { G. lemaneiformis (?) } \\
\text { (Coquimbo, Chile) }\end{array}$ & $\mathrm{COQ}$ & $5-20$ \\
\hline $\begin{array}{l}\text { G. bursa-pastoris } \\
\text { (Hawaii) }\end{array}$ & BPHI & $24-27$ & $\begin{array}{l}\text { Gracilariasp. } \\
\text { (Maullin, Chile) }\end{array}$ & VD & $9-20$ \\
\hline $\begin{array}{l}\text { G. coronopifolia J. Ag. } \\
\text { (Hawaii) }\end{array}$ & COR & $24-27$ & & & \\
\hline
\end{tabular}

whenever possible and, for some strains, tetrasporophytes also were used to compare the responses of the two phases. General culture procedures and medium have been described previously (N. Bird et al., 1977). Incubation was in water baths or growth chambers, and irradiance, from cool-white fluorescent lamps, was provided at $75 \mu \mathrm{E}$ $\mathrm{m}^{-2} \mathrm{~s}^{-1}$ on a $12: \overline{12} \mathrm{~h}(\mathrm{~L}: \overline{\mathrm{D}})$ cycle. Experimental temperatures ranged from $0^{\circ} \mathrm{C}$ to $36^{\circ} \mathrm{C}$, as indicated in Figure 1.

\section{Tolerance}

Apical segments about $10 \mathrm{~mm}$ long, 15 per culture vessel, were incubated for 6 weeks in culture tubes containing $50 \mathrm{ml}$ of medium and capped with "Kimble" closures. The cultures are not aerated, and the medium was changed weekly at the higher temperatures $\left(>20^{\circ} \mathrm{C}\right)$ and fortnightly at the lower temperatures. To test for effects of thermal shock, inocula were preconditioned for about 1 week at the highest non-lethal temperature before being subjected again to the initially lethal extremes of temperature. Material that did not grow during the experimental period, but was visually judged to have survived, was incubated at $20^{\circ} \mathrm{C}$ for a further period, and viability was assessed by subsequent growth. Assessment of tolerance was based simply on growth at the experimental temperature or after removal to more favourable conditions. 


\section{Growth}

Thirty apices of each isolate, $10 \mathrm{~mm}$ long, were incubated with aeration and weekly change of medium at the experimental temperatures for 3 weeks. Growth was assessed by four categories of mean increase in length (or weight for $G$, mammillaris, with branched apices): (1) maximum increase for the isolate, (2) increase at least $50 \%$ of maximum, (3) measurable increase, 20-50\% of maximum, and (4) no measurable increase or increase $<20 \%$ of maximum, disregarded as being possibly artifactual.

\section{Temperature and distribution records}

Oceanic temperatures used in our considerations are general for coastal waters (adapted from Gorshkov, 1976, 1979), and do not include local habitat variations. Temperature ranges for the specific habitat from which the experimental isolates were obtained (unpubl. observations) are included when available in Table 1.

Distribution records of species are derived from the available literature. For the western Atlantic, the nomenclature generally follows that of Taylor (1960), and starts from Dawson (1949) for the Eastern Pacific. For the eastern Atlantic, the floristic literature is rather more scattered, but the nomenclature here does not predate 1958 . We have updated the nomenclature according to recent publications, and make no unpublished amendments here; however, in discussing certain species, we consider the conventionally used specific epithet to be incorrect or doubtful, and have preferred to designate the taxon merely as Gracilaria sp.

\section{RESULTS AND DISCUSSION}

\section{Tolerance}

The results of all experiments are summarized in Figure 1. There were no noticeable differences in response between gametophytes and tetrasporophytes, and no further distinction is made between these phases. This is consistent with other observations on thermal responses of macroalgae with isomorphic generations (van den Hoek, 1982). A cautionary note is appropriate here: responses to temperature may be tempered to some degree by experimental conditions, and plants in the field may respond differently. The experimental results do serve, however, to indicate the approximate potential of species, and illustrate differences among them.

All species tolerated temperatures from $15^{\circ} \mathrm{C}$ through $24^{\circ} \mathrm{C}$. Species that did not survive $10^{\circ} \mathrm{C}$ were from warm-water areas with a minimum ambient temperature of more than $15^{\circ} \mathrm{C}$ and sometimes as much as $24^{\circ} \mathrm{C}$ (Table 1). In addition, species that tolerated $30^{\circ} \mathrm{C}$ or higher were also usually from warm-water habitats. However, a direct correlation between an isolate's range of tolerance and local field temperature is not always apparent. Isolate GTF of G. tikvahiae, for example, tolerated temperatures much lower than it would experience in nature, its range of tolerance being identical with that of its northern counterpart BAR. This suggests that thermal tolerance is uniform throughout the geographic range of a species and is not altered by adaptation to local conditions (cf. Bolton \& Lüning, 1982; Rietema \& van den Hoek, 1984), and that temperature ecotypes are not present in this species. 


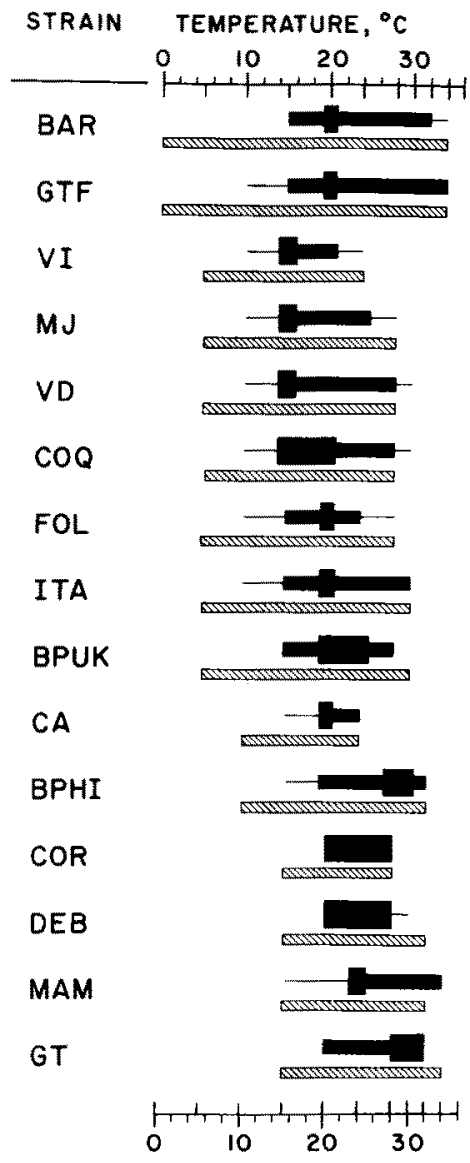

Fig. 1. Thermal ranges of tolerance (cross-hatched bars) and growth (solid bars) in isolates of Gracilaria. Three categories of growth are indicated, ranging from maximum (broadest bar) to measurable (single line, $20-50 \%$ of maximum). The experimental points are indicated on the temperature scale, and the names and sources of isolates are in Table 1

Only with $G$. foliifera (FOL) was preconditioning effective in extending the range of tolerance, and then only at the lower temperatures. This isolate survived $5^{\circ} \mathrm{C}$ when preconditioned at $10^{\circ} \mathrm{C}$. The inference is thus that thermal tolerance in most species of Gracilaria is not influenced by habitat temperature. Such stability contrasts with the ease with which germlings of the brown alga Fucus $L$. can be preconditioned to withstand subzero temperatures (Bird \& McLachlan, 1974), but it has already been pointed out (van den Hoek, 1982) that the short-term exposure employed in such studies is not comparable with the long-term conditions experienced in nature and used here.

The two strains of $G$. tikvahiae, BAR and GTF, responded identically despite their widely disparate origins, and had the broadest range of tolerance, $0^{\circ}$ to $34^{\circ} \mathrm{C}$. At $36^{\circ} \mathrm{C}$, however, both strains became moribund within several days. Of the taxa examined experimentally, G. tikvahiae spans the broadest range of latitudes (van den Hoek, 1982), and its eurythermal properties reflect its wide distribution. 


\section{Growth}

With the exception of G. mammillaris (MAM), the isolates grew well at $20^{\circ} \mathrm{C}$, and many showed maximum growth at this temperature. Maximum growth with some was limited to this temperature whereas with others it extended to higher temperatures. This upward extension generally occurred in warm-water species whose lower limits of thermal tolerance were $>10^{\circ} \mathrm{C}$ (Fig. 1). In the tropical isolates DEB and COR, maximum growth occurred between 20 and $28^{\circ} \mathrm{C}$ and in COR, extended to the upper limits of thermal tolerance. With warm-water isolates BPHI, MAM and GT, maximum growth required temperatures above $20^{\circ} \mathrm{C}$, around $24^{\circ} \mathrm{C}$ for MAM and $30^{\circ} \mathrm{C}$ for BPHI and GT. MAM grew well at $34^{\circ} \mathrm{C}$ during three weeks, although this temperature was ultimately lethal. Of all the isolates examined, MAM was the only one actually to show poor growth at $20^{\circ} \mathrm{C}$.

Isolates from temperate waters, CA excepted, displayed reasonably good growth below $20^{\circ} \mathrm{C}$ and, again with the exception of CA, all the isolates from the eastern Pacific showed maximum growth at $15^{\circ} \mathrm{C}$. None of the isolates from any area showed appreciable growth below $10^{\circ} \mathrm{C}$ and about $50 \%$ of the isolates failed to grow at this temperature.

Strains of G. tikvahiae, BAR and GTF, grew well over a broad range of temperature, about $16^{\circ}$. At $34^{\circ} \mathrm{C}$, the upper limits of tolerance, growth declined in BAR but continued to be reasonably good in GTF. Both strains grew reasonably well at $15^{\circ} \mathrm{C}$, and poorly or not at all at $10^{\circ} \mathrm{C}$. The seasonally cold habitat from which BAR was isolated did not enhance its potential for growth at temperatures less than $15^{\circ} \mathrm{C}$.

\section{Reproduction}

It has not been possible to separate reproduction from growth in Gracilaria. When plants are growing well, they become fertile; under conditions that reduce or prevent growth, fertility is suppressed. Temperature, nutrients, and light, including photoperiod, have had, in our experience, no effects on reproduction of the isolates beyond their direct influence on growth. We have been unable to prevent reproduction in healthy cultures of Gracilaria other than to block the formation of cystocarps by restricting fertilization of the female gametophyte. For this reason we have preferred to use segregated female gametophytes as experimental material.

\section{Temperature and geographic distribution}

\section{Western Atlantic}

The western Atlantic has a continuous mainland coastline lying roughly north-south between latitudes $65^{\circ} \mathrm{N}$ and $52^{\circ} \mathrm{S}$. A vast area of warm water, with a mean annual temperature around $25^{\circ} \mathrm{C}$, extends from Florida southward to southern Brasil. Except in the northern Gulf of Mexico, the mean 3-month minimum sea temperature in this region is at least $20^{\circ} \mathrm{C}$, and in most locations it is several degrees higher. South of Brasil, along the Argentine coast, minimum sea temperatures are cool, but at least $5^{\circ} \mathrm{C}$ in Tierra del Fuego. It is important to emphasize that north of Florida, large annual variations in temperature occur, exceeding $20^{\circ}$ in some locales, and minimum values of $0^{\circ} \mathrm{C}$ or less are attained around $40^{\circ} \mathrm{N}$. Temperature regimes clearly reflect circulation patterns in the 
western Atlantic. Cool water is transported northward along the southern coast of South America, and cold water southward along the coast of Atlantic Canada and New England. Warm water circulates in the central region of the Atlantic, between the Tropic of Capricorn and the Tropic of Cancer.

The Gracilaria flora of the western Atlantic is known reasonably well, perhaps better than on any other coastline of comparable length. We presently recognize about 30 species, while appreciating that taxonomic problems exist. It is unlikely, however, that taxonomic changes will greatly modify the general quantitative aspects of this Gracilaria flora.

The region with the largest number of Gracilaria species is the warm-water area between $30^{\circ} \mathrm{N}$ and $30^{\circ} \mathrm{S}$, from Florida to southern Brasil (Fig. 2), and including Bermuda.

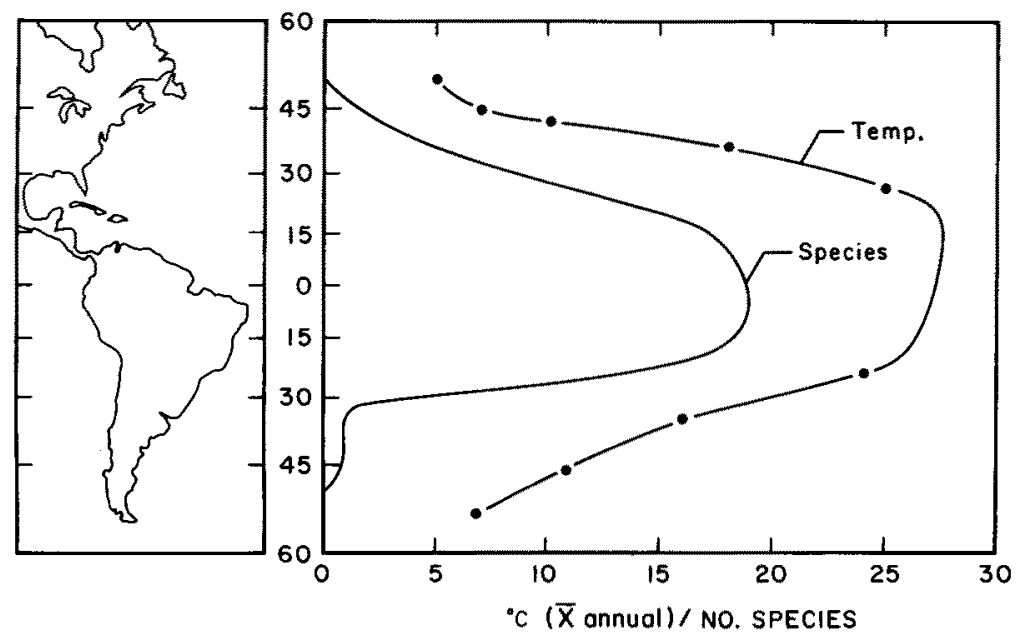

Fig. 2. Number of Gracilaria species in the western Atlantic relative to the mean sea temperature (adapted from Gorshkov, 1979)

There is little seasonal or spatial thermal variation in these waters, and the distribution of Gracilaria is, as far as records indicate, relatively uniform in the Gulf of Mexico and the Caribbean Sea. Near the middle of this warm-water region, however, the outflows of the Orinoco and Amazon rivers constitute a major perturbation. An extensive area is affected by this intrusion of fresh water, particularly north of the Amazon, and these rivers must be considered significant barriers to movement of algal species along the South American coast.

North and south of the warm-water area, the number of species of Gracilaria is sharply reduced. In the northern hemisphere, the reduction begins from Cape Canaveral northward. Temperature, however, remains relatively high $\left(>20^{\circ} \mathrm{C}\right)$ on offshore reefs of North Carolina, and some common tropical species persist there (Schneider, 1976). North of Cape Hatteras, where minimum temperatures fall below $15^{\circ} \mathrm{C}$ and may be lower than $0^{\circ} \mathrm{C}, \mathrm{G}$. tikvahiae is the only species to be found. This species extends to the southern Gulf of St. Lawrence and, at least north of Cape Cod, is restricted to lagoonal habitats where summer temperatures exceed normal coastline maxima.

In the southern hemisphere, cold-water upwelling in the vicinity of Cabo Frio 
coincides with a significant decrease in the number of species of Gracilaria south of the Tropic of Capricorn (Oliveira, 1984). Only one, or perhaps two, species occur in Uruguay, and south of the Plata River there are no records for Gracilaria apart from an apparently isolated population of a single species in Chubut Province, Argentina (C. Pujals, M. Mendoza, in verb.; in herb. BA). This species occurs in bays where few other algae are present, and where thermal maxima are about $17^{\circ} \mathrm{C}$ and minima about $6^{\circ} \mathrm{C}$ (Mayer, 1981). Although this species has not been recorded from farther south, the southern Argentine coast is poorly known floristically, and it is not possible to comment further on probable distribution. We suggest that this Argentine species is related to the flora of the eastern Pacific rather than the Atlantic. We are also aware of records of other Gracilaria species from the Falkland Islands (in herb. BM) and the Palmer Peninsula, Antarctica (Papenfuss, 1964; in herb. BA, NRCC); however, until we are able to confirm these determinations, and already the record for the Antarctic has been questioned (R. Moe, in litt.), these sites will not be considered further at this time.

Experimentally, the warm-water isolates from central Florida and the West Indies (DEB, MAM, GT) tolerated a minimum temperature of $15^{\circ} \mathrm{C}$ but did not survive at $10^{\circ} \mathrm{C}$. Moreover, these species required at least $20^{\circ} \mathrm{C}$ for significant growth $\left(24^{\circ} \mathrm{C}\right.$ for MAM), and the two West Indian isolates manifested maximum growth at higher temperatures. Their distribution thus would not be expected to extend beyond the tropics and, indeed, these species seemed to be restricted to this area. However, the isolate GT is poorly characterized, and it is not possible at present to comment on the general distribution of this taxon. Although we are not considering the geographical distribution of Hawaiian species, similar comments are applicable to the two isolates, COR and BPHI.

The remarkably eurythermal G. tikvahiae (BAR, GTF) is well suited to its broad, known latitudinal range from Atlantic Canada to at least Puerto Rico, and is one of the few north Atlantic species with such a wide distribution (van den Hoek, 1982). Its ability to grow at temperatures of $25-32{ }^{\circ} \mathrm{C}$ permits it to inhabit tropical waters, albeit at superoptimal thermal conditions. Indeed, it appears better equipped to withstand high extremes of temperature than some of the strictly tropical species tested (e.g. DEB, COR). Temperatures above $34^{\circ} \mathrm{C}$, which occur locally in Florida (Earle, 1969) and elsewhere in the tropics, would be lethal to $G$. tikvahiae and all other isolates examined; however, such temperatures do not occur in open waters and cannot be considered as limiting the distribution of G. tikvahiae (and others), although excluding it from specific habitats. As the only experimentally examined species to tolerate temperatures below $5^{\circ} \mathrm{C}, G$. tikvahiae also is able to withstand winter conditions in New England and Maritime Canada, provided that summer temperatures of around $20^{\circ} \mathrm{C}$ obtain long enough for significant growth to occur. From Cape Cod to the southern Gulf of St. Lawrence, such summer temperatures occur only in shallow embayments, and G. tikvahiae is confined to these specific habitats. Seasonally warm water is of sufficient duration for only one reproductive phase to attain maturity, suggesting that two years are required to complete the life history in nature. Maintenance of these populations may be largely by vegetative propagation (C. J. Bird et al., 1977), although it is noteworthy that sexual compatibility is maintained among not only the spatially isolated populations of eastern Canada, but also between these (BAR) and the Florida strain (GTF) with production of reproductively normal hybrids. North of the southern Gulf of St. Lawrence, either shallow embayments are absent, or seasonal periods of warm water are too short to support G. tikvahiae. Thus, 
the Gulf of St. Lawrence is the northern limit of distribution of this species in the northwestern Atlantic. We have yet to determine the southward limits of G. tikvahiae, but suspect its occurrence in the Caribbean Sea and perhaps Brasil (see van den Hoek, 1982).

\section{Eastern Pacific}

The continuous coastline of the western Americas, from the Gulf of Alaska to Tierra del Fuego, is relatively uniform except for the major identation of the Gulf of California, and dissection into islands at the higher latitudes. Coastal waters of the eastern Pacific are largely temperate, with only a relatively small area of warm water lying generally north of the equator to about $25^{\circ} \mathrm{N}$. Temperatures along this coast, as elsewhere, reflect patterns of oceanic circulation and, in this case, are complicated by extensive areas of upwelling and aperiodic incursions of warm water (El Niño) both north and south of the equator. The latter is the major perturbation on this coast and has been responsible for catastrophic disruptions of the biota (Smith, 1983). There are no major rivers to the Pacific from either of the American continents, and the substratum is generally favourable for algal development. Indeed, the marine flora from the Gulf of Alaska to southern Chile is relatively rich in species or with well-developed biomass. Most of this coast is, however, very exposed, and few if any species of Gracilaria are able to develop in areas of extreme exposure. Within the range of Gracilaria, from Chiloe northward to southern British Columbia, where there are few major bays or sheltered areas apart from the Gulf of California, the populations are disjunct.

The number of species of Gracilaria reported from the eastern Pacific is about the same as for the western Atlantic. Similarly, the number of species along the coast is directly correlated with the water temperature (Fig. 3). Here the number is largest in the Gulf of California, a relatively restricted latitudinal range. This cannot be due solely to meagre floristic records for neighbouring areas, as there are comparable reports on

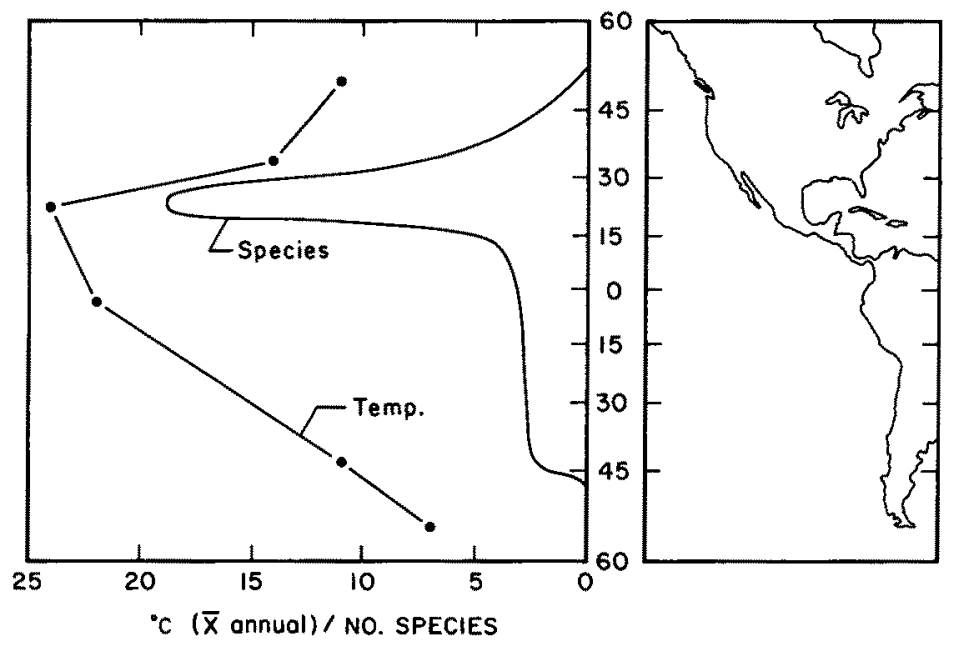

Fig. 3. Number of Gracilaria species in the eastern Pacific relative to the mean sea temperature (adapted from Gorshkov, 1976) 
Central America (e.g. Dawson, 1961b) and certainly the algal flora of California is well documented (Abbott \& Hollenberg, 1976). Rather, the area of warm water, with 3-month minimum temperature of $20^{\circ} \mathrm{C}$ or more, is very limited on this coast and many species are apparently confined to this area. It should be noted, however, that a number of eastern Pacific species of Gracilaria as presently understood have limited distributions or are known from one locality only. Not all species of more temperate coasts extend into the warmer water (e.g., G. peruana Picc. \& Grun.), and species distributions are generally more localized and discontinuous than in the Atlantic.

Northward from Baja California, there is a rapid decline in the number of species, to two in British Columbia, the known northern limits of Gracilaria in the eastern Pacific. Temperatures along this coast show little annual variation, and decline gradually toward the Gulf of Alaska, where the minimum and maximum values may be about $10^{\circ} \mathrm{C}$ and $15^{\circ} \mathrm{C}$, respectively. South of Baja California, the depletion of species is more gradual, partly because other species are added to the flora to replace those endemic to the Gulf of California (Dawson, 1961a). Additionally, these coastal waters remain relatively warm as far south as Peru. The reduction in number of Gracilaria species, however, parallels a decline in the total number of species in the flora (Gaines \& Lubchenco, 1982). Farther south, the pattern of declining numbers of Gracilaria species is ill-defined, possibly because of taxonomic "noise" resulting from few species being known in any one area, and there is no apparent trend along the South American coast. There have been no reports of Gracilaria south of Chiloé, and the genus is not encountered again in South America until about the same latitude on the Argentine (Atlantic) coast.

Along the Chilean coast, Gracilaria is found sporadically in the few bays and other habitats that afford sufficient shelter, but develops considerable biomass wherever it occurs. The species there are poorly understood, and the situation has been complicated by transplanting from one area to another for commercial purposes. In the vicinity of Chiloé, there may be two, possibly three species (Kim, 1970; Westermeier, 1981). Large biomasses of a species resembling $G$. verrucosa, and currently known by this name, develop in bays that have some inflow from rivers and annual temperature ranges of $9^{\circ}-20^{\circ} \mathrm{C}$. As the alga is harvested more or less continuously, significant growth must occur throughout most of the year. Maximum growth of isolate VD from this area occurs at $15^{\circ} \mathrm{C}$. As noted already and based on preliminary examination of this species, considering similarities in morphology and habitat, we speculate that it is conspecific with the Argentine entity. The present temperature regime of southern South America would seem to permit migration from one ocean to another, and certainly there is no lack of suitable habitat in the southern archipelago of Chile; however, lack of continuity suggests that populations in this region may also be relicts. Our knowledge of the western Atlantic species of Gracilaria and their distribution patterns leads us to consider that the Argentine population originated from the Pacific rather than the reverse. We further speculate that this species may range north in the Pacific to Vancouver Island, where it also is referred to as G. verrucosa, although incorrectly (Bird et al., 1982). Similarities in habitat and morphology support this view, although the northern isolate (VI) is less tolerant of warmer temperatures. Present-day temperatures in the eastern Pacific undoubtedly preclude the occurrence or migration of this species through the tropical areas.

Another species, G. lemaneiformis, occurs in commercial quantities in central Chile 
(Bahia Herradura), and has been successfully transplanted to the north (Bahia Mejillones del Sur). The annual temperature range in Bahia Herradura is from about $5^{\circ} \mathrm{C}$ to $20^{\circ} \mathrm{C}$. Previous experimental studies (Santelices \& Fonck, 1979) have shown growth to occur over the range $5^{\circ}$ to $30^{\circ} \mathrm{C}$, with maximum growth at $25^{\circ} \mathrm{C}$. Our own studies, using isolates from both Herradura (COQ) and Mejillones (MJ), suggest that exposure to $30^{\circ} \mathrm{C}$ for six weeks is lethal and that the optimum temperature for growth of COQ is from 15 to $20^{\circ} \mathrm{C}$. To the contrary, growth of $\mathrm{MJ}$ is more similar to that of isolate VD.

The distributional range of $G$. lemaneiformis recently was expanded greatly when Abbott (1983) reduced $G$. sjoestedtii, described from central California, to synonymy with this species. Thus, in North America, G. lemaneiformis ranges from Vancouver Island southward to Costa Rica (Abbott, 1983). In addition to being morphologically indistinguishable, the North and South American entities share similarities in habitat as well. In view of the Costa Rican record and despite the variable response of Chilean isolates to $30^{\circ} \mathrm{C}$, we suggest that $G$. lemaneiformis is capable of extending through the eastern Pacific tropics. Thus we consider this species and the eastern Pacific entity $G$. cf. verrucosa both to have extremely broad geographic ranges. Nevertheless, we recognize that work on both of these species is required before definitive conclusions on their distribution can be drawn.

The isolate Gracilaria sp. (CA), from Shelter Island, San Diego is notable for a narrow thermal range of tolerance and growth (Fig. 1). Temperature in its natural habitat ranges from $12^{\circ} \mathrm{C}$ to $23^{\circ} \mathrm{C}$ (Table 1), the maximum being close to the limits of tolerance for this species. Even its limited tolerance, however, would permit a very broad geographic distribution along the Pacific coast, excluding only the tropical regions. As we know nothing of the identity of this species, it is not possible to comment further on its possible distribution.

Northward from northern California, there are only two species of Gracilaria (Widdowson, 1974; Abbott \& Hollenberg, 1976), G. lemaneiformis (G. sjoestedtii) and $G$. cf. verrucosa, which coexist and range to southern Vancouver Island. Both species are usually relatively abundant when present, in bays and inlets where the temperatures are cool and vary little seasonally (Saunders \& Lindsay, 1979). Temperature does not seem to be the reason that these two species disappear from the flora northward along the British Columbian coast. Rather, there are probably other abiotic factors, not apparent at this time, excluding these species. In this regard, we cannot ignore the species of Gracilaria on the neighbouring Pacific coast of the Soviet Union (Makienko, 1979). In morphology, size (to $2 \mathrm{~m}$ long), and habitat where maximum temperatures may be only $14^{\circ} \mathrm{C}$ to $16^{\circ} \mathrm{C}$, these plants are comparable to $G$. cf. verrucosa of the eastern Pacific. Critical study of the Soviet species and comparison with the British Columbian entity are required.

\section{Eastern Atlantic}

In considering the eastern Atlantic, we ignore the major irregularities of the Mediterranean and Baltic Seas, and focus on the generally north-south oriented coastline from Norway to South Africa. In the north, large areas of temperate water extend to northern Norway, where there is an annual thermal range of $5^{\circ} \mathrm{C}$ to $15^{\circ} \mathrm{C}$ and much substrate available to algae. Southward, the temperature increases gradually to its maximum at about latitude $15^{\circ} \mathrm{N}$ (Fig. 4). Warm water is restricted to the central African coast, and has a noticeable seasonal variation in temperature, with the minimum near 


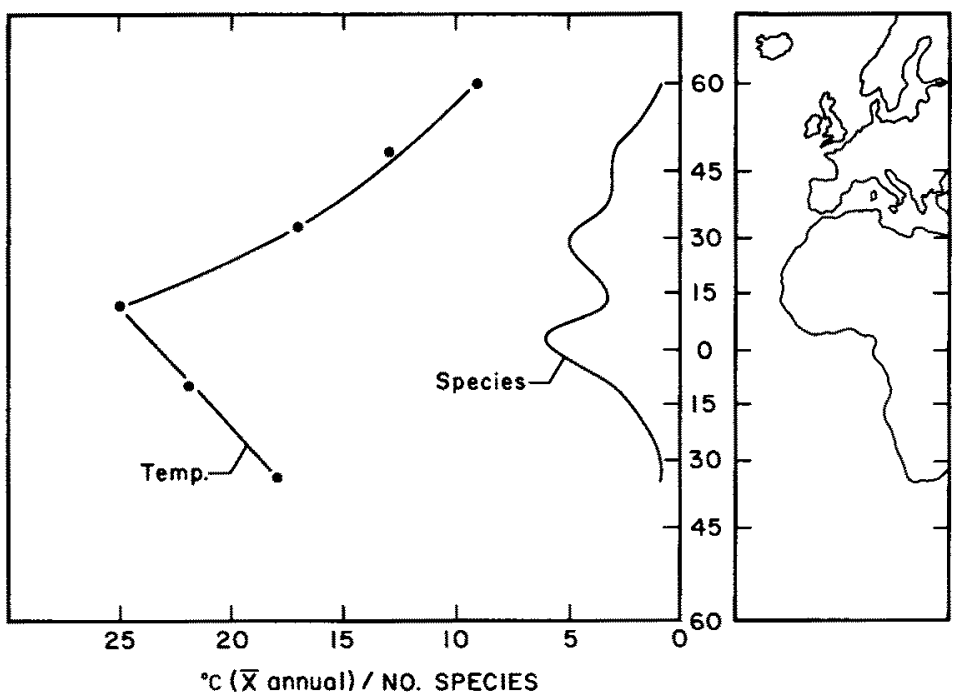

Fig. 4. Number of Gracilaria species in the eastern Atlantic (excluding the Mediterranean Sea) relative to the mean sea temperature (adapted from Gorshkov, 1979)

$20^{\circ} \mathrm{C}$. Not only is the area of warm water small, but much of it also is turbid. The Niger and Congo (Zaire) Rivers are the major discharges of fresh water into the eastern Atlantic, and are undoubtedly major barriers to the dispersal of marine plants and development of extensive floras. Upwelling also occurs along the tropical African coast, so that there may be periodic localized cooler water (Lawson \& John, 1982). Farther south, temperatures decline gradually but do not fall below $15^{\circ} \mathrm{C}$ in southernmost Africa. These southern temperate waters are continuous with those of southeastern Africa, with no apparent barriers to algal dispersal, as the land mass does not extend to the colder, higher latitudes.

The Gracilaria flora of the eastern Atlantic is ostensibly depauperate. This may reflect a deficiency in floristic records, although the European algal floras are certainly well known, and we are confident that few species of Gracilaria occur in these regions. This is not unexpected as these waters are temperate, with maximum seasonal temperatures of $20^{\circ} \mathrm{C}$ occurring only south of the Strait of Gibraltar. The same three species of Gracilaria are found along the European coastline and in Morocco are joined by three more species (although the European species $G$. bursa-pastoris here seems restricted to the Mediterranean coast). The species composition then changes from Senegal southward (Lawson \& John, 1982).

As in other tropical areas, we would expect a greater number of species from the warm-water region of Africa. This is not, however, borne out by the recent comprehensive treatment of the algal flora by Lawson \& John (1982). The sublittoral flora of most of the African coast is poorly known, though, and with future investigations of these habitats, the number of reported species of Gracilaria may increase. There have been few investigations along the south African coast, but we would not expect a significant increase in the number of species because of the temperate waters. Our lack of first-hand knowledge precludes any further comment here on the African flora. 
Gracilaria ranges north to southern Norway (about $53^{\circ} \mathrm{N}$ ), where the waters remain above $5^{\circ} \mathrm{C}$ throughout the year and reach maximum summer temperatures of nearly $15^{\circ} \mathrm{C}$. This is probably the highest latitude from which a species of Gracilaria is known for certain. Unlike Gracilaria in many areas of North and South America, the eastern Atlantic species do not occur in significant quantity in any one locale but are represented by scattered, occasional plants.

We have experimental data on thermal responses of two of the three European Atlantic species, but regrettably not for $G$. verrucosa, the type species of the genus. Both G. foliifera (FOL) and G. bursa-pastoris (BPUK) tolerate $5^{\circ} \mathrm{C}$, and the northern limit of both these species is the English Channel, where winter temperatures are about $5^{\circ} \mathrm{C}$. Gracilaria foliifera, however, requires acclimation to the colder temperatures, and a sudden decrease in temperature could thus be detrimental. The thermal properties of FOL would appear to justify the view that populations of $G$. foliifera in southern England are readily damaged in abnormally cold winters, as occurred in 1978/79 (G. T. Boalch, pers. comm.). Growth experiments suggest that $G$. foliifera is very seasonal at the northern limits of its distribution. At the same time, isolate FOL did not tolerate temperatures above $28^{\circ} \mathrm{C}$, which is of interest as the type locality of this species is the Red Sea, notable for high temperatures. Thus the conspecificity of the European and Red Sea populations can be questioned, as the data suggest that this species, or the northern European strain, is not well adapted to warm-water environments.

Identical ranges of thermal tolerance were shown by G. bursa-pastoris (BPUK) and the isolate from the Mediterranean Sea (ITA). In fact, G. bursa-pastoris may be a major species of the Mediterranean Sea, its type locality. This species has been reported south to Morocco, whereas $G$. foliifera is recorded from the Liberian-Cameroon coast, the area of maximum temperature in the eastern Atlantic. The experimental data suggest that $G$. bursa-pastoris could adapt well to conditions over much of the eastern Atlantic coast, perhaps better than $G$. foliifera, although it has not been recognized from any of the more southern sites along this coast.

\section{CONCLUSIONS}

The following statements pertain largely to the coasts of the Americas, as, for lack of information, we can draw few detailed conclusions about the eastern Atlantic species at this time.

(1) The number of species of Gracilaria present along a coastline correlates well with water temperature, and the basic assumption that temperature is directly responsible for distribution of this genus is supportable. Tropical waters harbour the greatest number of species, and it is correct to say that Gracilaria is a warm-water genus. In fact, in the regions we have considered, general oceanic temperatures are not too high to restrict the distribution of species of Gracilaria except in a very few cases. That is, there are generally no upper thermal barriers, although these exist in localized habitats where temperatures exceed $34^{\circ} \mathrm{C}$. Here we may note that few if any species of benthic seaweeds can tolerate temperatures above $35^{\circ} \mathrm{C}$ when submersed (Biebl, 1962, 1972). In the northern hemisphere, the area for which we have the most data, there is a close correlation between the number of species of Gracilaria and the total number of algal species in the flora (Gaines \& Lubchenco, 1982). This supports the general conclusion on the importance of temperature to the diversity of the flora. 
(2) Minimum temperatures are the major thermal barrier to distribution of Gracilaria. Rapid reduction in species numbers occurs where the 3-month minimum temperature falls below $20^{\circ} \mathrm{C}$ (Fig. 5), the minimum temperature required for significant

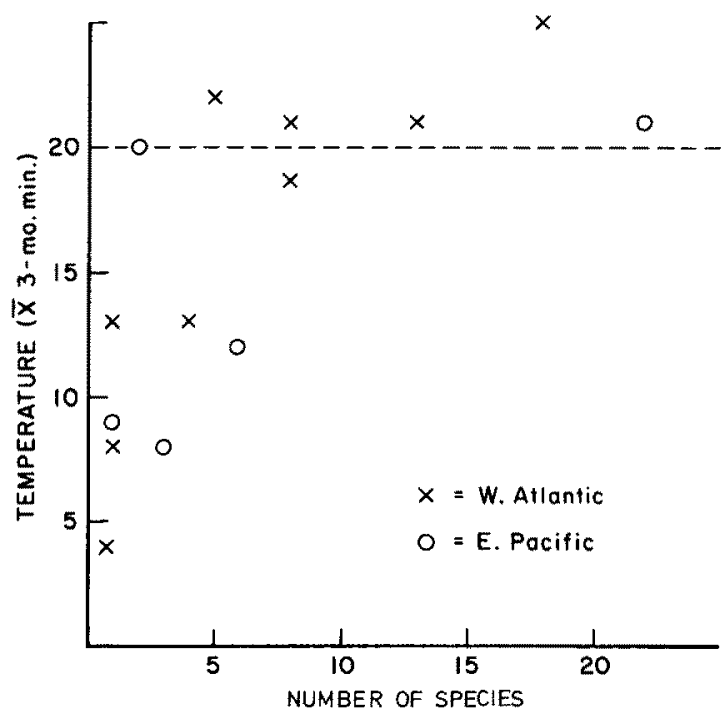

Fig. 5. Correlation between 3-month minimum temperature and the number of species of Gracilaria. Points indicate the number of species reported in specific floras

growth in many species. Thus, tropical species may extend into slightly cooler waters, but very few species are actually restricted to temperate waters. Further floristic and taxonomic study may show such "temperate" species to be more widely distributed than is presently believed.

(3) There is a general coincidence between minimum temperatures tolerated and the minimum temperature within the geographic range of the species, and we have little or no evidence for thermal ecotypes. Further, only one of our isolates could be preconditioned to lower temperatures, and even then, the range of tolerance was extended only about $5^{\circ}$. Most of the species that we have examined are capable of tolerating the mean maximum temperatures prevailing in the warm-water regions.

(4) Growth usually does not occur at the lower extreme of the temperature-tolerance range, but frequently continues at a reasonable rate at or above the upper limits of longterm tolerance. Maximum growth is most often at a narrow range of temperature. Reproduction occurs only when the plants are growing well.

(5) In warm-water areas, especially those with seasonal variation in temperature, species may be existing at least part of the time at superoptimal temperatures. For most warm-water isolates, however, maximum growth occurred close to the upper limits of tolerance, as well as at slightly lower temperatures.

(6) In temperate areas growth is undoubtedly seasonal, especially where there are thermal variations in the environment. Many of these species showed maximum growth at $20^{\circ} \mathrm{C}$ while growing well at $15^{\circ} \mathrm{C}$. Maximum growth of four of the isolates from the 
eastern Pacific occurred at $15^{\circ} \mathrm{C}$, and no isolate grew below $10^{\circ} \mathrm{C}$. We have not seen a "cold-water" species or strain of Gracilaria. Species of Gracilaria near their higher latitudinal limits of distribution in temperate waters thus may be under constraints of temperature plus time. Vegetative propagation may be a common mode of reproduction, and large biomasses can accumulate where there is little apparent competition from other species. Therefore, when the growing season is short, vegetative propagation can be important in maintaining populations. Moreover, apical tissue may not represent the absolute limits of thermal tolerance; basal discs of $G$. foliifera are more cold-tolerant than erect fronds (McLachlan \& Edelstein, 1977) and, like overwintered discs of $G$. tikvahiae (C. J. Bird et al., 1977), are capable of regeneration.

(7) We suggest that the Gracilaria floras of the western Atlantic, eastern Pacific and eastern Atlantic are distinct, with few if any species in common. Recent doubts cast on the wide, transoceanic distribution of some species of Gracilaria (Bird et al., 1982; Renfrew, 1983) support this view. These areas have been separated since the opening of the Atlantic Ocean in the Jurassic period and the closing of the Isthmus of Panama during the Pliocene epoch (Pielou, 1979). In view of the known distribution patterns of the species and the thermal restrictions we have seen experimentally, species of Gracilaria do not bridge the oceans or continents via the higher latitudes. These areas have, therefore, been separated for sufficient time for a distinct flora to develop in each.

Acknowledgements. We thank N. Lewis and M. Greenwell for technical assistance, S, Gallagher for material from Florida, and H. J. Black for use of laboratory space. Financial support from the Royal Netherlands Academy of Arts and Sciences and the Foundation "Groninger Universiteitsfonds'" enabling the first author to participate in the Seaweed Biogeography Workshop, is gratefully acknowledged.

\section{LITERATURE CITED}

Abbott, 1. A., 1983. Some species of Gracilaria (Rhodophyta) from California. - Taxon 32, 561-564.

Abbott, I. A. \& Hollenberg, G. J., 1976. Marine algae of California. Stanford Univ. Press, Stanford, $827 \mathrm{pp}$.

Biebl, R., 1962. Seaweeds. In: Physiology and biochemistry of algae. Ed. by R. A. Lewin. Acad. Press, New York, 799-815.

Biebl, R., 1972. Temperature resistance of marine algae. - Proc. int. Seaweed Symp. 7, 23-28.

Bird, C. J. \& McLachlan, J., 1974. Cold-hardiness of zygotes and embryos of Fucus (Phaeophyceae, Fucales). - Phycologia 13, 215-225.

Bird, C. J., Edelstein, T. \& McLachlan, J., 1977. Studies on Gracilaria. Experimental observations on growth and reproduction in Pomquet Harbour, Nova Scotia. - Naturaliste can. 104, 245-255.

Bird, C. J., Meer, J. P. van der \& McLachlan, J., 1982. A comment on Gracilaria verrucosa (Huds.) Papenf. (Rhodophyta: Gigartinales). - J. mar. biol. Ass. U. K. 62, 453-459.

Bird, N., McLachlan, J. \& Grund, D., 1977. Studies on Gracilaria. 5. In vitro life history of Gracilaria sp. from the Maritime Provinces. - Can. J. Bot. 55, 1282-1290.

Bolton, J. J. \& Lüning, K., 1982. Optimal growth and maximal survival temperatures of Atlantic Laminaria species (Phaeophyta) in culture. - Mar. Biol. 66, 89-94.

Dawson, E. Y., 1949. Studies of northeast Pacific Gracilariaceae. - Occ. Pap. Allen Hancock Fdn 7, $1-105$.

Dawson, E. Y, 1961a. Marine red algae of Pacific Mexico. P. 4: Gigartinales. - Pacif. Nat. 2, 191-343.

Dawson, E. Y., 1961b. Plantas marinas de la zona de las mareas de El Salvador. - Pacif. Nat. 2, 389-461.

Druehl, L. D., 1981. Geographical distribution. In: The biology of seaweeds. Ed. by C. S. Lobban \& M. J. Wynne. Univ. California Press, Berkeley, 306-325. 
Earle, S. A., 1969. Phaeophyta of the eastern Gulf of Mexico. - Phycologia 7, 71-254.

Gaines, S. D. \& Lubchenco, J., 1982. A unified approach to marine plant-herbivore interactions. II. Biogeography. - A. Rev. Ecol. Syst., 13, 111-138.

Gorshkov, S. G., 1976. World ocean atlas. 1: Pacific Ocean. Pergamon Press, Oxford, 340 pp. (Russ.: Atlas okeanov).

Gorshkov, S. G., 1979. World ocean atlas. 2: Atlantic and Indian Oceans. Pergamon Press, Oxford, 352 pp. (Russ.: Atlas okeanov).

Hay, M. E. \& Norris, J. N., 1984. Seasonal reproduction and abundance of six sympatric species of Gracilaria Grev. (Gracilariaceae; Rhodophyta) on a Caribbean subtidal sand plain. - Proc. int. Seaweed Symp. 11,63-72.

Hoek, C. van den, 1982. The distribution of benthic marine algae in relation to the temperature regulation of their life histories. - Biol. J. Linn. Soc. 18, 81-144.

Kim, D. H., 1970. Economically important seaweeds in Chile-I. Gracilaria. - Botanica mar. 13, 140-162.

Lawson, G. W. \& John, D. M., 1982. The marine algae and coastal environment of tropical West Africa. - Nova Hedwigia (Beih.) 70, 1-455.

Makienko, V. F, 1979. Investigation of promising algae [Gracilaria verrucosa (Huds.) Papenf.] for cultivation in the Far East. - Trudy vses. nauchno-issled. Inst. morsk. rybn. Khoz. Okeanogr. 138, 51-60.

Mayer, A. M. S., 1981. Studies on Gracilaria sp. in Bahia Arredondo, Chubut Province, Argentina. Proc. int. Seaweed Symp. 10, 705-710.

McLachlan, J. \& Edelstein, T., 1977. Life-history and culture of Gracilaria foliifera (Rhodophyta) from south Devon. $-J$, mar. biol. Ass. U.K. 57, 577-586.

Oliveira, E. C. de, 1984. Taxonomic criteria in the genus Gracilaria Grev. (Rhodophyta) - an experience with the western Atlantic species. - Proc. int. Seaweed Symp. 11, 55-58.

Papenfuss, G. F., 1964. Catalogue and bibliography of Antarctic and sub-Antarctic benthic marine algae. - Antarctic Res. Ser. 1, 1-76.

Pielou, E. C., 1979. Biogeography. Wiley-Interscience, New York, 351 pp.

Renfrew, D. E., 1983. An investigation of the taxonomic relationship between Gracilaria tikvahiae McLachlan and Gracilaria bursapastoris (Gmel.) Silva. M. Sc. Thesis, Acadia Univ., Wolfville, $198 \mathrm{pp}$.

Rietema, H. \& Hoek, C. van den, 1984. Search for latitudinal ecotypes in Dumontia contorta (Rhodophyceae). - Helgoländer Meeresunters. 38, 389-399.

Round, F. E, 1981. The ecology of algae. Cambridge Univ. Press, Cambridge, 653 pp.

Santelices, B. \& Fonck, E., 1979. Ecologia y cultivo de Gracilaria lemanaeformis. - Act. Symp. Algas mar. Chile. 1, 165-200.

Saunders, R. G. \& Lindsay, J. G., 1979. Growth and enhancement of the agarophyte Gracilaria (Florideophyceae). - Proc. int. Seaweed Symp. 9, 249-255.

Schneider, C. W., 1976. Spatial and temporal distributions of benthic marine algae on the continental shelf of the Carolinas. - Bull. mar. Sci. 26, 133-151.

Smith, R. L., 1983. Peru coastal currenty during El Niño: 1976 and 1982. - Science, N.Y. 221, $1397-1399$.

Taylor, W. R., 1960. Marine algae of the eastern tropical and subtropical coasts of the Americas. Univ. of Michigan Press, Ann Arbor, $870 \mathrm{pp}$.

Westermeier, R., 1981. The marine seaweed of Chile's tenth region (Valdivia, Osorno, Llanquihue and Chiloê). - Proc. int. Seaweed Symp. 10, 215-220.

Widdowson, T. B., 1974. The marine algae of British Columbia and northern Washington: revised list and keys. P. 2: Rhodophyceae (red algae). - Syesis 7, 143-186. 